Даниела Д. Ломенова

Библиотека Матице српске, Нови Сад

daniela.lomen@gmail.com
Стручни рад

UDK 027.7(437.6)"1919/2019"

https://doi.org/10.18485/bibliotekar.2020.62.1.7

\title{
КРОЗ КОРЗО ПРОШЛОСТИ И САДАШЊОСТИ УНИВЕРЗИТЕТСКЕ БИБЛИОТЕКЕ У БРАТИСЛАВИ
}

Сажетак: У раду су представљени историјски развој и данашње стање Универзитетске библиотеке у Братислави (УКБ) - најстарије и највеће научне библиотеке у Словачкој Републици. Такозвана „Универзитка” прославила је стогодишњицу постојања 2019. године. Свој рад започела је на месту некадашње библиотеке Угарског краљевског Елизабетиног универзитета, преузевши од ње зграду, опрему и фондове. Уредио ју је владин комесар, њен први директор Јан Емлер, који је дошао по позиву из прашке Јавне царско-краљевске универзитетске библиотеке и оставио највећи печат у историји развоја УКБ својим организаторским способностима и стваралачким и конструктивним радом. УКБ је данас смештена у три историјска објекта - споменика културе од националног значаја - у Кларисеуму, Палати Угарске краљевске коморе и Палати Леополда де Паулија. Своју делатност наставља у монументалном окружењу барокног амбијента, у којем се традиција спаја са модернизацијом услуга и успешном реализацијом пројеката помоћу савремених информационих технологија.

Кључне речи: Универзитетска библиотека у Братислави, историјат, Словачка Република, Јан Емлер.

\section{Увод}

Универзитетска библиотека у Братислави (у даљем тексту: УКБ) ${ }^{1}$ припада културним и образовним институцијама, које су међу првима основане у Словачкој, односно, тадашњој Чехословачкој Републици. Сврха

\footnotetext{
1 UKB - Univerzitná knižnica v Bratislave - садашњи назив библиотеке (нап. аутора).
} 
оснивања ове институције било је подстицање развоја високог школства, науке и библиотекарства. Основана је 10. октобра 1919. године непосредно годину дана после распада Аустроугарске монархије (1867-1918), а настала је у околностима, у којима су се, уз процесе формирања самосталних држава, уводили нови библиотечки закони и доносиле заједничке одлуке Словака и Чеха. После Првог светског рата створиле су се нове прилике у остваривању давних тежњи свих народа бивше монархије - ослобађање од јарма, стицање слободе, бирачког права, грађанске равноправности, осмочасовног радног времена и слободе изражавања и штампе. Ове тековине биле су од великог значаја за даљи друштвени и културни развој свих новонасталих држава, па и Словачке. У таквим, и даље тешким околностима, словачко и чешко библиотекарство закорачило је заједничким путем у трајању од седамдесет година, почевши од стварања Чехословачке Републике 1918. године, све до 1992. године, тј. њиховог раздвајања на две самосталне и независне државе. Од великог значаја за словачко и чешко библиотекарство у то време било је и увођење Закона о јавним општинским библиотекама (Zákon o verejných knižniciach obecných č. 430/1919 Z. z.) под бр. 430/1919 3. 3., који је донела Народна скупштина Чехословачке Републике 22. јула 1919. године. У Словачкој је почео да се примењује шест година касније у односу на Чешку - 1925. године. Иако се закон односио само на народне библиотеке, био је од кључног значаја за развој словачког библиотекарства али и културног живота њеног народа. ${ }^{2}$ Његов допринос се одразио на уређивање, одржавање и финансирање активности јавних библиотека, попуњавање библиотечких фондова, пружање услуга преко позајмице и читаоница свим слојевима друштва и на тај начин омогућио је подизање нивоа образовања у друштву. Тако се стварао систем народних библиотека који је послужио као пример и осталим европским државама. У оваквим околностима настала је Универзитетска библиотека у Братислави или „Универзитка” како је још зову од милоште.

Братислава је град у коме високо школство има релативно дугу традицију. Још је краљ Матија Корвин (1443-1490) основао Универзитет (Академију) Истрополитану (Universitas (academia) Histropolitana) у Братислави, 1467. године. После његове смрти нестаје и ова академија, а са њом и припадајућа библиотека (већи и драгоцени део фонда се изгубио, а остатак је завршио у приватним збиркама). Скоро двеста година Братислава је била без високих школа. Фондови библиотека институција, о којима ће бити

2 Štefan Pasiar, Dejiny slovenských ludových knižníc (Martin: Osveta, 1957), 143, 145-146. 
речи, слили су се попут реке у исти фонд, који је на крају припао Универзитетској библиотеци у Братислави.

Крајем 18. века, Краљевска академија (Academia regia) пресељена је из Трнаве у Братиславу, у Кларисеум - данашње седиште УКБ. Имала је правни и филозофски смер, с тим да је филозофски укинут 1850. године школском реформом и академија добија нови назив - Царска краљевска правна академија (Cisárska královská právnická akadémia). Године 1851. академију су преселили у објекте данашњег Универзитета Коменског, а са радом престаје 1914. године. Поседовала је богату библиотеку чији је већи део припао Католичкој гимназији (Katolícke gymnázium). Седиште Католичке гимназије је такође било у Кларисеуму од 1786. до 1908. године. После измештања гимназије из овог објекта, остаје у Кларисеуму тзв. стара библиотека (фонд је грађен од оснивања ове гимназије па до 1850. године) која постаје депозит града. Градско представништво Братиславе преузело је под своју управу и библиотеку Удружења грађана Напредни кружок (више од 5.000 свезака) са циљем да се изгради и постави темељ јавној градскској библиотеци. Под називом Јавна библиотека слободног краљевског града Братиславе (Verejná knižnica slobodného královského mesta Bratislavy) основана је 1900. године са седиштем у Палати угарске краљевске коморе, објекту који је касније припао УКБ. Фондове је увећавала богатим књижним поклонима, а 1904. године измештена је у Надбискупску палату (Primaciálny palác). Како би наставила рад, добила је од градских званичника мали део свог некадашњег фонда као основу за поновни почетак. Њен данашњи назив је Градска библиотека у Братислави.

Угарски парламент 1912. године доноси закон о оснивању универзитета у Братислави. Тада је основан Угарски краљевски Елизабетин универзитет (Úhorská královská Alžbetina univerzita), именован по царици и краљици Елизабети, и свечано је отворен 13. октобра 1914. године. Градски званичници су библиотеци новог универзитета уступили просторије Кларисеума, дајући јој на поклон већи део фонда Јавне библиотеке слободног краљевског града Братиславе, драгоцени депозит - тзв. стару библиотеку Католичке гимназије и библиотеку Царске краљевске правне академије. Укупни фонд библиотеке на почетку њеног постојања чинио је око 50.000 свезака.

Трајање Угарског краљевског Елизабетиног универзитета у Братислави било је кратког даха јер су ратни услови онемогућили даљи рад ове установе и довели до њеног постепеног гашења. Универзитет престаје да ради 1919. године. Убрзо после тога 27. јуна 1919. године, новим законом под бр. 375 Збирке закона и прописа (čís. 375 Sbírka zákonů a nařízení), донесена је одлука да на његовом месту буде основан Чехословачки државни универзитет 
(Československá štátna univerzita) - највећа научна и образовна институција, која је именована по чувеном учењаку - Јану Амосу Коменском. Законом је утврђено и то да предавања на универзитету буду на словачком и чешком језику. Први пут у историји Словачка је имала свој универзитет, који је пружао могућност стицања највишег образовања на матерњем језику.

Уз Чехословачки државни универзитет изграђена је, у виду самосталног института, и универзитетска библиотека, данашња УКБ. Библиотека је од Угарског краљевског Елизабетиног универзитета преузела зграду, опрему, фондове и обавезе, али је своје зачетке почела да гради на новим концептима и полазиштима. Овај разноврстан материјал у целини сачињавао је поприличан фонд, претежно на латинском, немачком и мађарском језику, међутим, због своје тематике није одговарао студентима, ни тадашњим научним истраживачима. Поједине семинарске библиотеке факултета, у склопу Угарског краљевског Елизабетиног универзитета, слабо су биле опремљене књигама из неких других научних дисциплина (као на пример из историје и књижевности словенских народа, и уопште, Словенства). Због тога је било неопходно да се изгради нова библиотека, која ће бити у складу и у духу језика предавања на новом Чехословачком државном универзитету. Нова библиотека је тада добила званичан назив Библиотека Универзитета Коменског (Knihovňa Univerzity Komenského). Још један назив је у међувремену имала - Библиотека Словачког универзитета (Knižnica Slovenskej univerzity) јер се настанак нове државе 1938. године, прве Словачке Републике, одразио и на целокупно функционисање библиотеке.

Библиотека је, такође, грађена са намером да буде централна библиотека која би сакупљала целокупно словачко књижевно и научно стваралаштво и уједно би представљала словачку националну библиотеку. Дакле, основни књижни материјал УКБ у време свог оснивања и настанка, састојао се од поклоњеног фонда Јавне библиотеке слободног краљевског града Братиславе (23.715 свезака), библиотеке Царске краљевске правне академије (30.181 свезак), од библиотеке Католичке гимназије, коју су звали и језуитска библиотека (6.894 свеска) и новог материјала библиотеке Угарског краљевског Елизабетиног универзитета (24.036 свезака), што је у укупном броју сачињавало 84.826 свезака. На словачком језику је било врло мало књига у преузетом фонду, чак у незнатном броју. За девет година свог постојања, УКБ је сакупила више од 100.000 књига. ${ }^{3}$

Richard Horna, “Bratislava jako universitní město”, u Československá republika: Bratislava, Kraus Franc (Bratislava: Mestská rada; Berlin: Dari, 1928), 36-37, 39. http://digitalna.kniznica.info/ zoom $/ 52105 /$ view?page $=45 \& \mathrm{p}=$ separate $\&$ tool $=$ info\&view $=0,0,3116,3925$ (преузето 16. 5. 2020). 
Иако је библиотека новооснованог Универзитета Коменског била у основи, послању и називу повезана са универзитетом, ипак није постала његов саставни део и своју је активност развијала шире. Уз своје главно усмерење да обавља класичну делатност једне универзитетске библиотеке, обављала је, како је речено, и дужности националне библиотеке (скупљала је и водила документацију словачке књижевности и других књижевности и штампаних публикација са територије Словачке и публикација о Словачкој), то јест, као прва библиотека у Словачкој, почела је да добија обавезни примерак Словачке, који и данас прима. ${ }^{4}$ Назив универзитетска библиотека упућује на универзални садржај њеног фонда, а функцију националне библиотеке обављала је до 1954. године, док није установљена Матица словачка у Мартину, као Национална словачка библиотека. Од те године УКБ је по статуту универзална, државна, научна библиотека, те је тако постепено прешла из библиотеке академског типа у јавну библиотеку и стекла данашњи назив Универзитетска библиотека у Братислави. Њен оснивач је Министарство културе Словачке Републике.

\section{Кратак историјат зграда УКБ или, прича о три куће на крају корза ${ }^{5}$}

Првобитно седиште данашње УКБ било је смештено у Кларисеуму комплексу зграда бившег манастира и цркве сестара Клариса. И данас се налази на овом месту, а уз овај комплекс, додељена су УКБ још два објекта, споменика културе - Палата Угарске краљевске коморе (Palác Uhorskej královskej komory) 1951. и Палата Леополда де Паулија (Palác Leopolda de Pauliho) 1957.

Кларисеум се налази на месту најстаријег манастира у Братислави, који је првобитно припадао женском црквеном реду цистерцита (у првој половини 13. века). Крајем 13. века прелази у руке реда сестара Клариса, које су ту боравиле до 1782. године, док није наложено наредбом цара

Zostavil Tibor Trgiňa, Univerzitná knižnica v Bratislave: Multifunkčné kultúrne centrum (Bratislava: Univerzitná knižnica v Bratislave, 2005), 25-30, 39.

5 Део поглавља „прича о три куће на крају корза” се односи на три објекта, у којима се данас налази седиште Универзитетске библиотеке у Братислави а око њих се простире корзо, односно, данас пешачка зона. 
Јозефа II укидање појединих монашких редова. После њиховог одласка објекат је прешао у власништво државе и адаптиран је за потребе Царско краљевске правне академије (1784-1850) и Католичке гимназије (17861908). Једна од занимљивости је да је и Бела Барток, велики мађарски композитор и пијаниста, похађао ову гимназију. Каснијих година је у згради било једно време и седиште поште и већ споменуте библиотеке Угарског краљевског Елизабетиног универзитета. Данас је у овом најстаријем објекту смештен Кабинет рукописа и старих и ретких књига, Централни дата архив, Одељење за рестаурацију докумената, Музички кабинет, Депозитна библиотека НАТО и Информационо-документациони центар УНЕСКО и ОУН. ${ }^{6}$

С временом су просторије Кларисеума постајале тесне за улагање властитих фондова. Нису ни испуњавале услове хигијене, будући да су биле хладне, мрачне са много влаге. Кларисеум, такође, архитектонски није био прилагођен функцијама и делатности библиотеке. Осим тога што су јој се властити фондови повећавали, од половине четрдесетих година пристизале су и књиге из конфискованих дворских и манастирских библиотека, које су поверене библиотеци под привремену управу. Ова тешка ситуација решена је тако што су библиотеци додељене још две, раније споменуте грађевине - Палата Угарске краљевске коморе 1951. године и Палата Леополда де Паулија 1957. године.

Палата Угарске краљевске коморе грађена је у периоду од 1751. до 1753. године. Изнад самог улаза у Палату налази се спомен-плоча посвећена владарки Марији Терезији, чијом је одлуком наложено да се палата изгради. Овде је било седиште Угарске коморе - највише финансијске установе у Угарској, до 1782. године, тј. до тренутка њеног затварања. Осим Угарске коморе, кроз историју су на овом месту нашли уточиште и Угарски сабор (1802-1848), разне службе попут телеграфске службе, метеоролошке станице, правосудних органа, државне управе, службе за катастар, Јавне библиотеке слободног краљевског града Братиславе и др. На крају је ова Палата додељена 1951. године Универзитетској библиотеци у Братислави (у то време се звала Библиотека Словачког универзитета). ${ }^{7}$ У њеним просторијама се данас налазе канцеларија директора, стручна одељења и страни фондови - библиотеке: Инфо УСА, Аустријска библиотека, Центар за руске

6 https://www.ulib.sk/files/sk/spravy/archiv/2019/univerzitna-kniznica-bratislave_historiasucasnost_2019.pdf (преузето 20.5.2020).

7 Zostavil Tibor Trgiňa, Univerzitná knižnica v Bratislave: 1919-2009 (Bratislava: Univerzitná knižnica v Bratislave, 2009), 6, 26, 34, 35, 37, 38. 
студије. Поред ових збирки у УКБ постоје и Британски центар, Немачка библиотека, Чешка библиотека и Збирка Виктора С. Маматеја.

Палата Леополда де Паулија најпре је представљала објекат који се углавном изнајмљивао патрицијским породицама, док су његови власници живели у предњем делу палате. Објекат је променио неколико власника, а спомиње се као средњовековна грађанска кућа у архивским списима из петнаестог века. Средњовековну грађанску кућу, која је претходно стајала на месту Палате, 1775. године откупљује управник царске својине Леополд де Паули и даје да се на том месту изгради Палата са мањим павиљоном у дворишном врту. Када је 1957. пренета у руке УКБ, наредних година је реконструисана заједно са павиљоном, а дограђена је и зграда са пет спратова као библиотечки магацин. Данас се ту налазе читаонице и одељења која пружају главне библиотечко-информационе услуге корисницима Библиотеке. ${ }^{8}$

У дворишном врту ове Палате налази се биста Франца Листа и Листов павиљон у стилу рококоа из 18. века у коме је деветогодишњи Франц Лист 1820. године држао концерт за градско племство. Та тврдња, међутим, није ни дан-данас потврђена, али је Павиљон по њему добио данашњи назив. У дворишном делу Павиљона одржавају се концерти, изложбе, беседе а половином осамдесетих година у њему је отворена летња читаоница. ${ }^{9}$

\section{„... Историја инстутуција се не односи само на зграде и њихову прошлост већ њу чине и људи..."10}

У новој Чехословачкој држави Словачка је у поређењу са Чешком имала недостатак стручног кадра из области културе, школства и библиотекарства. Стога је прихватала помоћ чешке интелигенције која је долазила у Словачку да јој помогне у изградњи школства, културе, библиотека и

8 https://www.ulib.sk/files/sk/spravy/archiv/2019/univerzitna-kniznica-bratislave_historiasucasnost_2019.pdf (преузето 20.5. 2020).

9 Zostavil Tibor Trgiňa, Univerzitná knižnica v Bratislave: Multifunkčné kultúrne centrum (Bratislava: Univerzitná knižnica v Bratislave, 2005), 39, 41.

10 Zostavovatel’ Dušan Lechner, Budovy Univerzitnej knižnice v Bratislave v premenách času : zborník k 85. . výročiu (Bratislava: Univerzitná knižnica v Bratislave, 2004), 6. (цитат преузет као поднаслов). 
библиотекарства. Са таквим намерама је послат у УКБ из Прага, владин комесар и главни библиотекар Јан Емлер (Jan Emler 1877-1951), поставши уједно и њен први директор. На молбу професора Камила Крофта, тадашњег шефа Одсека за високе школе при Министарству школства, Емлер долази у Братиславу са задатком да уреди, организује и опреми библиотеку. Преузима фонд од поменутих 84.826 свезака, зграду и опрему. Пошто су на Универзитету Коменског биле у току припреме предавања за јесењи семестар, потребно је било што пре предочити план набавке публикација, на начин усклађен са студијским потребама факултета. У Братиславу је дошао из прашке Јавне царско-краљевске универзитетске библиотеке, односно данашње Националне библиотеке у Прагу, где је радио у својству правника. Требало је да се задржи три месеца док не заврши све задатке, али му се боравак одужио на једанаест активних година. За то време, предано радећи, уредио је и проширио фонд са поклонима личних библиотека познатих личности тог доба, попут евангелистичких свештеника Адама и Сама Халупке и учитеља и библиографа Људовита Владимира Ризнера (око 2.000 свезака). Уредио је да се добије из тадашње Националне и универзитетске библиотеке из Прага 5.000 дупликата старих бохемика из купљене библиотеке старог племићког рода Лобковица, затим је организовао откуп бохемикалних дела из библиотеке Константина Јиречека у Бечу, и многе друге. Занимљив је и податак, о поклонима из Краљевске академије у Београду, које је било уврштено у фонд Славистичког одељења. ${ }^{11}$ Од значајних фондова ваља споменути и Штурову библиотеку, коју је УКБ добила 1923. године у Емлерово време од Славистичког института у Братислави, чијом је библиотеком некада управљао Људовит Штур (Ludovít Štúr, 1815-1856). Тај фонд је разврстан по језицима а за нас је занимљиво што су у њој заступљена, осим словачких, чешких, пољских и српска дела. ${ }^{12}$ Од часописа најзаступљенији наслови су на српском језику јер је Штурова генерација показивала велико интересовање за њих, али је и велики број Срба у то време боравио на студијама у Словачкој (часописи Данища, Глас нароgа, Гласник, Голубииа, Јавор, Майииа, Пояунавка, Позоришиее и др.). ${ }^{13}$

11 Sostavil Ján Čaplovič, Z bratislavských knižníc: sborník k 30. výročiu Knižnice Slovenskej univerzity, (Bratislava: Tatran, 1950), 5, 6, 23.

12 Bronislava Svobodová, Kamila Fircáková, "Ludovít Štúr a Univerzitná knižnica v Bratislave", Bulletin Univerzitnej knižnice v Bratislave č. 1 (2006): 7-12.

13 Viera Bunčáková, „Slovanské časopisi v Knižnici 'Ústavu řeči a literatúry československé'“, u $Z$ bratislavských knižníc: sborník k 30. výročiu Knižnice Slovenskej univerzity, sostavil Ján Čaplovič (Bratislava: Tatran, 1950), 73-76. 
Јан Емлер је, такође, успео за библиотеку да издејствује право добијања једног обавезног примерка са територије Словачке и на тај начин проширио је фонд публикацијама на чешком и словачком језику. Основао је 1923. године први Централни (узајамни) каталог словачких библиотека, касније назван Емлеров каталог, који се и данас чува у УКБ, у посебно реконструисаном каталошком ормару. У њему се огледа високи ниво стручности тадашњих библиотекара а представља драгоцен историјски и библиотечки извор, који сведочи о развоју словачког библиотекарства. ${ }^{14}$ Јан Емлер је често представљао Чехословачку на међународним библиотечким конференцијама и својом преданошћу у раду, оставио је највећи траг у УКБ. Додељене су му значајне награде међу којима је и одликовање Витеза ордена Легије части. ${ }^{15}$

Библиотечке послове овог преданог и пожртвованог библиотекара који је поставио чврсте темеље УКБ, преузима др Јозеф Шуцнер (Josef Schützner, 1888-1977) као наследник његовог започетог дела. Уз ова имена, наравно, треба споменути и остале значајне њуде, који су руководили УКБ попут Људовита Захара (Ludovít Zachar, 1888-1967), Винцента Кућика (Vincent Kútik, 1917-1995), Тибора Тргиња (Tibor Trgiňa, 1943-), Игора Хрушовског (Igor Hrušovský, 1907-1978), Марије Штефановичове (Mária Štefanovičová, 1905-1976), Јана Чапловича (Ján Čaplovič, 1904-1976) и др. Занимљивост је што је име Јана Чапловича повезано и са нашим просторима јер је у месту Ковачица провео детињство и обављао једно време функцију евангелистичког свештеника, оставивши тако неизбрисив траг и у нашем културном простору. ${ }^{16}$

\section{Codices manuscripti Bibliothecae universatis Bratislavensis ${ }^{17}$}

У оквиру својих вредних библиотечких фондова, издвајају се збирке рукописа, које су по пореклу и језику претежно европског карактера. Обухватају распон од 12/13. до 20. века. Прве примерке рукописа је УКБ

14 https://www.ulib.sk/files/SKP/emler_informacia.pdf (преузето 16. 5. 2020).

15 http://biography.hiu.cas.cz/Personal/index.php/EMLER_Jan_1.8.1877-28.5.1951 (преузето 20. 4. 2020).

16 Ján Čaplovič, "Môj otec“, Studia bibliographica Posoniensia 1/2007 (Bratislava: Univerzitná knižnica v Bratislave, 2007), 24.

17 Поднаслов преузет из истоимене публикације аутора Имриха Котвана, у преводу: Рукописи Универзитетске библиотеке у Братислави (нап. аутора). 
наследила из три библиотеке, које су ушле у основ њених фондова (из библиотеке Католичке гимназије, тј. старе језуитске 112, Царске краљевске правне академије 11 и Јавне библиотеке слободног краљевског града Братиславе - 1 свезак). Касније су рукописне збирке пристизале куповином и поклонима (рукописи из личних збирки Људовита Владимира Ризнера, Адама и Сама Халупке, Алојза Колиске, Јозефа Кветослава Холуба, Павела Бујнака, А. В. Михајлова, Јозефа Белаја, Беле Михаелиса, Павела Зохе, Душана Јурковича, затим из манастирских и племићких збирки, збирки разних институција, збирке рукописних музикалија и др.). ${ }^{18}$

Кабинет рукописа, старих и ретких књига основан је 1953. године као самостално специјално и научно одељење, с намером да се посебно окупе, обраде и истраже историјски фондови. С обзиром да се повећало интересовање за инкунабулама, разлог је био већи да се отвори посебно одељење, чији су се историјски фондови претходно обрађивали заједно са осталим публикацијама. У фонду се налази око 1.310 библиографских јединица рукописа средњоевропског порекла, 284 свеска оријенталних рукописа, приближно 2.500 књига из 16. века, елзевире, јудаике и око 500 инкунабула у периоду од 1460. до 1500. године.

Као занимљивост можемо да наведемо најстарију инкунабулу у УКБ која потиче из 15. века (око 1460. године) на латинском језику „Tractatus rationis et conscientiae“. Изашла је из штампарије Јохана Гутенберга у Мајнцу, од словачког аутора Матије из Кракова (Matthaeus de Cracovia, око $1355-1410){ }^{19}$

Посебан и уникатни фонд у Универзитетској библиотеци од изузетне вредности, уписан у Светску баштину УНЕСКО 1997. године, представља Башагићева збирка исламских рукописа. УКБ је ову збирку купила 1924. године од Сафвета-бега Башагића (1870-1934), истакнутог песника, преводиоца, оријенталисте и политичара, у то време директора Земаљског музеја у Сарајеву, по коме је и добила име. ${ }^{20}$ Збирку сачињава 598 рукописа у 284 свеске, од чега су 393 арапска наслова, 117 турских и 88 персијских, а међу штампаним књигама, која садрже 496 дела (у 365 свезака) може се

18 Imrich Kotvan, Rukopisy Univerzitnej knižnice v Bratislave, (Bratislava: Univerzitná knižnica v Bratislave, 1970), 7,

19 Imrich Kotvan, „Rukopisné a vzácne fondy, ich budovanie a ochrana v Univerzitnej knižnici“, u Univerzitná knižnica v Bratislave 1969-1979: zborník z príležitosti 60. výročia. (Bratislava: Univerzitná knižnica v Bratislave, 1980), 73, 74, 76.

20 Ján Molnár, Orientálne tlače z knižnice Safveta bega Bašagića v Univerzitnej knižnici v Bratislave (Bratislava: Univerzitná knižnica v Bratislave, 1980), I. 
наћи 145 арапских, 338 турских и 8 персијских наслова. ${ }^{21}$ Није најјасније под каквим је околностима колекција доспела у УКБ, нити о томе сведочи неки аутентичан документ. Једино се преко писма директора Јана Емлера упућеног Министарству за школство и националну просвету у Прагу сазнаје да господин Башагић намерава да прода драгоцену збирку и шта она све садржи. ${ }^{22}$ Већи део фонда је обрадио и уредио сам Башагић. Године 1917. је чак издао каталог под називом Пойис оријенйалних рукойиса моје библиоиеке (Сарајево, 1917. изашао као посебан отисак у „Гласнику Земаљског музеја у Босни и Херцеговини”, XXVIII, 1916, 3. и 4, стр. 207-290). ${ }^{23}$ Спомиње да је збирку почео да сакупља још његов отац Ибрахим, један од последњих босанских писаца, који је писао на турском језику. Фонд тематски садржи углавном дела из области верских наука: куран, традиција, верско право, догматика, мистика и молитве. Осим филозофије, ту су заступљена дела из психологије, метафизике и логике. Од осталих научних дисциплина можемо да споменемо још астрономију, математику, политику, законе, историју, лексикографију, граматику, метрику, реторику и поетику. Комплетна збирка је стручно обрађена, рестаурисана и дигитализована. ${ }^{24}$

\section{Библиотека данас}

Данас је УКБ највећа културна, информациона, научна и образовна институција из области библиотечке делатности, представљајући мултифункционални културни центар. Из класичне библиотеке с временом је прешла у једну модерну библиотечко-информациону институцију, са богатим фондом од скоро три милиона библиотечких јединица. Њена пажња је усмерена на библиотечке, информационе, библиографске, научноистраживачке и културно-образовне активности и бави се следећим пословима:

21 Comparaverunt Jozef Telgársky et Zuzana Banská, Catalogus slovacicorum in Bibliothaeca Universitatis Posonii usque ad annum 1918 impressorum (Codex praecursorius) Volumen I.A-C (Univerzitná knižnica v Bratislave, Národné knižničné centrum: Bratislava, 1999), XIV.

22 Klára Meszárosová, "Knihy Safveta Bega Bašagića vo fondoch Univerzitnej knižnice v Bratislave“, Studia bibliographica Posoniensia 1/2006 (Bratislava: Univerzitná knižnica v Bratislave, 2006), 95, 96 .

23 Imrich Kotvan, Rukopisy Univerzitnej knižnice v Bratislave (Bratislava: Univerzitná knižnica v Bratislave, 1970), 19.

24 https://www.ulib.sk/sk/stredisko-unesco/pamat-sveta/program-pamat-sveta/basagicovazbierka/ (преузето 22. 5. 2020). 
• прикупља и трајно чува библиотечку документацију Словачке Републике;

- депозитна је библиотека за НАТО и ОУН;

- депозитна је библиотека и информациони центар за УНЕСКО;

- депозитна је библиотека за све научно-стручне радове, брањене у Словачкој Републици, која води њихов библиографски регистар;

- управља узајамним каталогом серијских публикација библиотека у Словачкој Републици;

- управља седиштем националне агенције за међународну идентификацију серијских публикација (ISSN);

- води службу за међубиблиотечку позајмицу и представља народни центар за међународну међубиблиотечку позајмицу;

- координира међународну библиотечко-информациону сарадњу, врши послове рестаурације, конзервације и услуге фотокопирања.

У оквиру својих главних активности, УКБ обавља следеће задатке:

- гради и даје на коришћење фонд домаћих и страних публикација, разне изворе информација из области друштвених и природних наука, приручнике, белетристику;

- гради историјски библиотечки фонд непериодичних и периодичних публикација, научно-стручних радова и аудио-визуелних докумената;

- гради и даје на коришћење фонд званичних докумената органа Словачке Републике;

- пружа комплексне библиотечко-информационе услуге;

- подржава модернизацију развоја библиотечких и информационих услуга у оквиру информационог система у Словачкој Републици. ${ }^{25}$

25 Ján Molnár, Orientálne tlače z knižnice Safveta bega Bašagića v Univerzitnej knižnici v Bratislave (Bratislava: Univerzitná knižnica v Bratislave, 1980), I. 


\section{Закључак}

Универзитетска библиотека у Братислави пружа широки спектар услуга академској и културној јавности. Осим примарних задатака заштите и трајног чувања културне баштине Словачке Републике, прикупљања и представљања свих врста грађе својим корисницима, уједно, промовише историју књижне културе и културне баштине широкој јавности кроз изложбе, стручне екскурзије, објављивање стручних радова у периодичним публикацијама и зборницима и кроз представљање резултата научноистраживачких радова и пројеката на домаћим и страним конференцијама. С обзиром на то да је научноистраживачка делатност по традицији у основи њеног рада, резултате својих истраживања презентује и преко властитих издања, а реализује их преко научних, стручних, образовних и културноваспитних догађаја. Помоћу нових информационих технологија, то јест дигитализацијом библиотечке грађе, у атрактивном и модерно дизајнираном корисничком окружењу даје увид корисницима у њене богате фондове.

\section{Literatura}

1. Bunčáková, Viera. "Slovanské časopisi v Knižnici 'Ústavu řeči a literatúry československé"”. U Z bratislavských knižníc: sborník k 30. výročiu Knižnice Slovenskej univerzity, sostavil Ján Čaplovič. Bratislava: Tatran, 1950.

2. Čaplovič, Ján. "Môj otec". Studia bibliographica Posoniensia 1 (2007).

3. Čaplovič, Ján, sost. Z bratislavských knižníc: sborník k 30. výročiu Knižnice Slovenskej univerzity. Bratislava: Tatran, 1950.

4. Historický ústav AV ČR, "Biografický slovník českých zemí", Historický ústav AV ČR, http://biography.hiu.cas.cz/Personal/index.php/EMLER_Jan_1.8.187728.5.1951 (preuzeto 20. 4. 2020).

5. Horna, Richard. "Bratislava jako universitní město". U Československá republika: Bratislava, Kraus Franc. Bratislava: Mestská rada; Berlin: Dari, 1928. http:// digitalna.kniznica.info/zoom $/ 52105 /$ view? page $=45 \& \mathrm{p}=$ separate $\&$ tool $=$ in fo\&view=0,0,3116,3925 (preuzeto 16. 5. 2020).

6. Kotvan, Imrich. Rukopisy Univerzitnej knižnice v Bratislave. Bratislava: Univerzitná knižnica v Bratislave, 1970.

7. Kotvan, Imrich. „Rukopisné a vzácne fondy, ich budovanie a ochrana v Univerzitnej knižnici“. U Univerzitná knižnica v Bratislave 1969-1979: zborník z príležitosti 60. Výročia. Bratislava: Univerzitná knižnica v Bratislave, 1980. 
8. Lechner, Dušan, zost. Budovy Univerzitnej knižnice v Bratislave v premenách času: zborník k 85. výročiu. Bratislava: Univerzitná knižnica v Bratislave, 2004.

9. Meszárosová, Klára. "Knihy Safveta Bega Bašagića vo fondoch Univerzitnej knižnice v Bratislave“. Studia bibliographica Posoniensia 1 (2006).

10. Molnár, Ján. Orientálne tlače z knižnice Safveta bega Bašagića v Univerzitnej knižnici $v$ Bratislave. Bratislava: Univerzitná knižnica v Bratislave, 1980.

11. Pasiar, Štefan. Dejiny slovenských ludových knižníc. Martin: Osveta, 1957.

12. Svobodová, Bronislava a Kamila Fircáková. "Ludovít Štúr a Univerzitná knižnica v Bratislave". Bulletin Univerzitnej knižnice v Bratislave, č. 1 (2006).

13. Telgársky, Jozef et Zuzana Banská, comparaverunt. Catalogus slovacicorum in Bibliothaeca Universitatis Posonii usque ad annum 1918 impressorum (Codex praecursorius.) Volumen I.A-C. Bratislava: Univerzitná knižnica v Bratislave, Národné knižničné centrum, 1999.

14. Trgiňa, Tibor, zost. Univerzitná knižnica v Bratislave: 1919-2009. Bratislava: Univerzitná knižnica v Bratislave, 2009.

15. Trgiňa, Tibor, zost. Univerzitná knižnica v Bratislave: Multifunkčné kultúrne centrum. Bratislava: Univerzitná knižnica v Bratislave, 2005.

16. Univerzitná knižnica v Bratislave. "História_súčasnost 2019“, Univerzitná knižnica v Bratislave, https://www.ulib.sk/files/sk/spravy/archiv/2019/univerzitna-kniznica-bratislave_historia-sucasnost_2019.pdf (preuzeto 20.5. 2020).

17. Univerzitná knižnica v Bratislave. "Poslanie knižnice“, Univerzitná knižnica v Bratislave, https://www.ulib.sk/sk/o-kniznici/poslanie-kniznice/ (preuzeto 7. 5. 2020).

18. Univerzitná knižnica v Bratislave. "Bašagičova zbierka”, Univerzitná knižnica v Bratislave, https://www.ulib.sk/sk/stredisko-unesco/pamat-sveta/program-pamat-sveta/basagicova-zbierka/ (preuzeto 22. 5. 2020).

19. Univerzitná knižnica v Bratislave. "Emler informácia", Univerzitná knižnica v Bratislave, https://www.ulib.sk/files/SKP/emler_informacia.pdf (preuzeto 16. 5. 2020). 


\title{
Daniela D. Lomenova
}

Matica Srpska Library, Novi Sad

daniela.lomen@gmail.com

\section{ALONG THE PROMENADE OF THE PAST AND PRESENT OF THE UNIVERSITY LIBRARY IN BRATISLAVA}

\begin{abstract}
This paper presents the historical development and current state of the University Library in Bratislava - the oldest and largest scientific library in the Slovak Republic. The so-called "Univerzitka" celebrated its centenary in 2019. It replaced the former library of the Hungarian Royal Elizabeth University, taking over its building, equipment, and collections. It was arranged by the government commissioner and its first director Jan Emler, who was invited from the Prague Imperial and Royal Public and University Library and who, with his organizational skills and creative and constructive work, left the greatest mark on the history of the University Library development. Today, the University Library is housed in three historic buildings - cultural monuments of national importance - the Clariseum, the Palace of the Hungarian Royal Chamber, and the Leopold de Pauli Palace. It continues with its activities in the monumental baroque environment, in which tradition is combined with the modern services and the successful realization of projects with the help of new information technologies.
\end{abstract}

Keywords: University Library in Bratislava, history, Slovak Republic, Jan Emler.

Примљено: 22. маја 2020.

Исправке: 15. јуна 2020.

Прихваћено: 30. јуна 2020. 